International Research Journal of Management, IT \& Social Sciences
Available online at https://sloap.org/journals/index.php/irjmis/
Vol. 6 No. 4, July 2019, pages: 169 173
ISSN: 2395-7492
https://doi.org/10.21744/irjmis.v6n4.670

\title{
Customers Trust Mediation: Effect of CSR and Service Quality towards e-WOM
}

Ni Made Rastini ${ }^{\text {a }}$ Nyoman Nurcaya ${ }^{b}$

Article history:

Received: 09 March 2019

Accepted: 31 May 2019

Published: 10 July 2019

Keywords:

CSR;

electronic word of mouth;

$e$-WOM;

service quality;

trust;

\begin{abstract}
This study aims to explain the effect of Corporate Social Responsibility activities, service quality on customer trust in PT. Bali Regional Development Bank and explained that customer trust encourages customers to do e-word of mouth to others. To achieve this goal, 100 people are used by Bank X customers spread across Bali Province and will be taken by purposive sampling with questionnaires as the method of data collection. Data is processed using Structural Equation Modeling analysis tools. The results of this study indicate that trust mediates the effect of service quality and corporate social responsibility to e-WOM at PT Bank X. The results of this study are expected to be able to contribute ideas to the banking industry, especially PT. Bank X in building long-term trust. The long-term trust of customers will make PT. Bank X can still compete and even be superior to other banks operating in Bali Province. The advantages of PT. BPB Bali will affect the pace of development in Bali Province through the assistance of MSMEs as one of the CSR programs that it does.
\end{abstract}

2395-7492@ Copyright 2019. The Author. This is an open-access article under the CC BY-SA license (https://creativecommons.org/licenses/by-sa/4.0/) All rights reserved.

\section{Author correspondence:}

Ni Made Rastini,

Faculty of Economics and Business, Udayana University, Denpasar, Indonesia.

Email address: rasumaputri80@gmail.com

\section{Introduction}

The intense competition in the banking industry requires PT. Bank X, hereinafter referred to as PT. Bank X as the only bank owned by the Provincial Government of Bali, designed the right strategy to be able to compete with other banks. As a development bank, commercial banks, and regional cash holders of PT. Bank X is required to be able to provide good quality services to its customers. Service quality is a dynamic condition that effects products, services, people, processes and environments that meet or exceed expectations (Tjiptono, 2002). This makes PT. Bank X must have the right marketing strategy so that customers get good quality service. Good service quality will foster customer confidence in the bank's commitment to the service it promises. In addition to paying attention to the quality of service

${ }^{\text {a }}$ Faculty of Economics and Business, Udayana University, Denpasar, Indonesia

${ }^{\mathrm{b}}$ Faculty of Economics and Business, Udayana University, Denpasar, Indonesia 
PT Bank X also has a high Corporate Social Responsibility (CSR) program for the community. According to Kotler and Lee (2005), CSR that is implemented appropriately both in the social, economic and environmental fields can provide many benefits for the company, one of which is customer/customer trust. The customer's trust has the potential to cause the information to other communities on the quality of service received by the customer.

Technological advancements have changed the way people engage in social interactions, such as communication or sharing information through online media by utilizing social networking Facebook, Twitter, Instagram, Whats App, Line and so on. The advancement of information technology is used by business people to compete in conducting marketing activities, one of which is to use electronic Word of mouth (e-WOM). According to Jalilvand (2012), states that e-WOM is a "venue" or a place that is very important for consumers to give their opinions and are considered more effective than WOM offline, because of the level of accessibility and broader reach. In general, Electronic communication Word of mouth (e-WOM) is the development of communication Word of mouth (WOM) which is effect by the internet. The behavior of e-WOM is one of the results of customer assessment on a company that is created from the overall business activities that shape value and customer trust in the company, these positive activities include Corporate Social Responsibility (CSR) and service quality (Dewi et al., 2017; Nehru, 2016).

\section{Literature Review and Hypothesis Development}

Corporate Social Responsibility and the quality of the company's services if developed properly will create a positive impression on the product and company. This will create an emotional bond between the community and the company so that it will be able to make a brand better known by the community. Prasetya \& Purwanegara (2010), states that if the public sees the impression on a company's CSR program, the customer will tell the product to others by utilizing technological advancements such as social networking or often called Electronic Word of Mouth (eWOM). Electronic Word of mouth is one of the customer assessment results in companies that are created from all business activities that shape value in a company. E-WOM is something we do every day as a way of communicating so that it will become an effective marketing method (Semuel \& Elianto, 2010). If customer trust is formed, it will encourage product users to conduct e-WOM behavior to others. In marketing, it is very important to maintain customer trust in order to maintain the sustainability of the company and also maintain relationships with customers. This is because customers always hope that the brands/products they buy will produce positive and beneficial results for their customers and their environment (Lau \& Lee, 1999).

\section{The Effect of Service Quality on Trust}

Al-Rousan et al., (2010), found that service companies must strive to maintain superior service quality over their competitors to obtain and maintain customer trust. Thus the proposed hypothesis:

$H_{1}$ : Service Quality has a positive and significant effect on Trust

\section{The Effect of Corporate Social Responsibility on Trust}

The research conducted by Pramono Hari Adi (2015), found that the variable social responsibility (CSR) had a significant effect on customer trust. The sample used was 78 respondents using accidental sampling method and using data analysis techniques namely regression analysis techniques. Thus the hypothesis submitted:

$\mathrm{H}_{2}$ : Corporate Social Responsibility (CSR) has a positive and significant effect on Trust

\section{The Effect of Trust on e-WOM}

Research conducted by Sari et al., (2019), found that Customer Trust has a positive and significant effect on e-Word of Mouth. The sample used by 128 respondents the analytical method used in this study was one sample T-Test, simple linear regression, and moderation, independent sample T-Test, one-way ANOVA. Thus the hypothesis can be formulated:

$H_{3}$ : Trust has a positive and significant effect on e-WOM

Trust mediates the effect of service quality, CSR on e-WOM

Nareeman \& Hassan (2013), show that CSR, service quality has a positive and significant effect on customer trust. With the existence of CSR in a company, making the company better understand and increase specific knowledge of its customers, this will have an impact on customer satisfaction (Mcwilliams, 2006). Research conducted by Indriani $\&$ Nurcaya (2015), found that customer trust had a significant and positive effect on WOM, and trust significantly mediated the quality of service to (word of mouth) WOM. Samples were taken as many as 110 respondents with the 
purposive sampling method. Data collection questionnaires by using a 5-point Likert scale, to measure 11 indicators. The analysis technique used is Path analysis. Thus, the hypothesis proposed is:

$\mathrm{H}_{4}$ : trust positively and significantly mediate the effect of service quality and CSR on e-WOM

\section{Materials and Methods}

This research was conducted on customers of Bank X, which are spread in 9 districts and cities in Bali Province. The population of this study is all PT. Bank X, which has been active for the past 6 (six) months. The number of samples used in this study is 100 respondents because they have met the requirements to be able to use Maximum Likelihood (M) as the estimation model. In taking samples in the study used non-probability sampling technique that is sampling techniques that do not provide equal opportunities or opportunities for each element or member of the population to be selected as a sample. The sampling technique in question is Purposive Sampling, which is a sampling technique with certain criteria. The data analysis technique used is descriptive statistical analysis and Structural Equation Modeling or SEM, which is operated through the AMOS 20.0 program (Nuryani et al., 2018; Sari et al., 2018; 2019).

\section{Results and Discussions}

\subsection{Direct Effect}

Table 1

Direct Effect

\begin{tabular}{|c|c|c|c|c|c|c|c|}
\hline & & & $\begin{array}{l}\text { Estimate } \\
\text { Unstandardized }\end{array}$ & S.E. & $\begin{array}{l}\text { Estimate } \\
\text { Standardize }\end{array}$ & C.R. & $\mathrm{P}$ Value \\
\hline Trust & $<---$ & Quality & .193 & .093 & .221 & 2.076 & .038 \\
\hline Trust & $<---$ & CSR & .223 & .072 & .442 & 3.085 & .002 \\
\hline e-WOM & $<---$ & Quality & .389 & .163 & .257 & 2.391 & .017 \\
\hline e-WOM & $<---$ & Quality & .292 & .114 & .389 & 2.557 & .011 \\
\hline e-WOM & $<---$ & Trust & .547 & .185 & .299 & 2.959 & .003 \\
\hline
\end{tabular}

Primary Data, 2019

Based on the estimation results of standardized regression measures in Table 1 it can be seen that the path coefficient of Service Quality on Trust is 0.193 with a significance level of 0.038 . This shows that there is a significant effect between Service Quality and Trust. The CSR construct has a significant effect on Trust with a path coefficient of 0.223 with a significance value of 0.002 .

Table 1 can also show that the path coefficient of service quality on e-WOM is 0.389 with a significance level of 0.017. This shows that there is a significant effect between the quality of services to e-WOM. The CSR construct has a significant effect on e-WOM with a path coefficient of 0.292 with a significance value of 0.011 . Likewise, the trust construct has a significant effect on e-WOM with a path coefficient of 0.547 with a significance value of 0.003 .

\subsection{Indirect Effect}

Table 2

Indirect Effect

\begin{tabular}{lll}
\hline Effect & Construct & Standardized Estimates \\
\hline Direct Effect & Kualitas Pelayanan - Kepercayaan & 0.221 \\
CSR -Kepercayaan & 0.565 & \\
Kepercayaan - e-WOM & 0.299 & 0.06 \\
Pengaruh Tak langsung & Kualitas Pelayanan-e-WOM & \\
CSR - e-WOM & 0.169 & \\
\hline
\end{tabular}

Rastini, N. M., \& Nurcaya, N. (2019). Customers trust mediation: effect of CSR and service quality towards e-WOM. International Research Journal of Management, IT and Social Sciences, 6(4), 169-173. https://doi.org/10.21744/irjmis.v6n4.670 


\begin{tabular}{lll}
\hline Pengaruh Total & Kualitas Pelay-e-WOM & 0.323 \\
CSR - e-WOM & 0.558 & \\
Kepercayaan - e-WOM & 0.299 & \\
\hline
\end{tabular}

Data Primer, 2019

\section{Conclusion}

There is a significant effect between Quality of Service on e-WOM activities of customers of PT, Bank X There is a significant effect between CSR on e-WOM activities of customers of PT, Bank X, There is a significant effect between Trust in e-WOM activities of customers PT, Bank X Belief significantly mediates the effect of servant quality and CSR on e-WOM activity activities of customers PT Bank X.

By paying attention to the results of these studies it is recommended to foster the interest of the community to become customers of PT. Bank X as the only regional government-owned bank in Bali, it is recommended that the banks to give more personal attention to their customers and intensively conduct socialization on CSR activities carried out will not burden the cost of service to customers. Thus a positive story about PT, Bank X will be able to grow the interest of the community to become customers and indirectly involve the community in building Bali in the future.

Conflict of interest statement and funding sources

The authors declared that they have no competing interest.

\section{Statement of authorship}

The authors have a responsibility for the conception and design of the study. The authors have approved the final article.

\section{Acknowledgments}

Limitations of time, costs and capabilities possessed by researchers allow research results to be not maximal. To be able to make a more optimal contribution to the Indonesian Banking industry, in Bali, in particular, it can be continued by adding other variables such as brand image, experience, and other variables. The use of more samples with a wider area of observation will also be able to add relevant information in accordance with the objectives of the research conducted. Thus the results of this study are very useful to foster a love of society towards banking institutions owned by the Regional Government of Bali so that they can contribute to building Bali in the future. 


\section{References}

Al-Rousan, M. R., \& Mohamed, B. (2010). Customer loyalty and the impacts of service quality: The case of five star hotels in Jordan. International journal of human and social sciences, 5(13), 886-892.

Dewi, I. G. A. A. O., \& Dewi, I. G. A. A. P. (2017). Corporate social responsibility, green banking, and going concern on banking company in Indonesia stock exchange. International Journal of Social Sciences and Humanities, 1(3), 118-134. https://doi.org/10.29332/ijssh.v1n3.65

Hari Adi, P., \& Adawiyah, W. R. (2018). The impact of religiosity, environmental marketing orientation and practices on performance: A case of Muslim entrepreneurs in Indonesia. Journal of Islamic Marketing, 9(4), 841-862. https://doi.org/10.1108/JIMA-09-2016-0067

Indriani, A. A. S. I., \& Nurcaya, I. N. Pengaruh kualitas pelayanan terhadap word of mouth yang dimediasi oleh kepercayaan pelanggan pada pt. auto bagus rent a car denpasar.

Jalilvand, M. R., \& Samiei, N. (2012). The impact of electronic word of mouth on a tourism destination choice: Testing the theory of planned behavior (TPB). Internet Research: Electronic Networking Applications and Policy, 22(5), 591-612.

Kartajaya, H. (2007). Boosting Loyalty Marketing Performance: Menggunakan Teknik Penjualan Customer Relationship Management, dan Servis untuk Mendongkrak Laba. Mizan Pustaka.

Kartajaya, H. (2008). New wave marketing. Jakarta: Gramedia Pustaka Utama.

Kotler, P., \& Lee, N. (2005). Best of breed: When it comes to gaining a market edge while supporting a social cause,"corporate social marketing" leads the pack. Social marketing quarterly, 11(3-4), 91-103. https://doi.org/10.1080\%2F15245000500414480

Lau, G. T., \& Lee, S. H. (1999). Consumers' trust in a brand and the link to brand loyalty. Journal of Market-Focused Management, 4(4), 341-370. https://doi.org/10.1023/A:1009886520142

McWilliams, A., Siegel, D. S., \& Wright, P. M. (2006). Corporate social responsibility: Strategic implications. Journal of management studies, 43(1), 1-18. https://doi.org/10.1111/j.1467-6486.2006.00580.x

Nareeman, A., \& Hassan, Z. (2013). Customer perceived practice of CSR on improving customer satisfaction and loyalty. International Journal of Accounting and Business Management, 1(1), 30-49.

Nehru, R. (2016). Corporate social responsibility \& education for sustainable development. International Research Journal of Engineering, IT \& Scientific Research, 2(3), 72-81.

Nuryani, N. N. J., Satrawan, D. P. R., Gorda, A. A. N. O. S., \& Martini, L. K. B. (2018). Influence of human capital, social capital, economic capital towards financial performance \& corporate social responsibility. International Journal of Social Sciences and Humanities, 2(2), 65-76. https://doi.org/10.29332/ijssh.v2n2.128

Prasetya, A., \& Kato, M. (2011, April). Employees' perception towards the performance assessment system and salary system. In Proceeding from ICETD (International Conference on Economics, Trade, and Development)-Bali Island (pp. 196-200).

Sari, D. M. F. P., \& Pradhana, I. P. D. (2018). Brand name, image, word of mouth towards buying habits and customer loyalty online shop. International Research Journal of Management, IT and Social Sciences, 5(2), 216-226.

Sari, D. M. F. P., \& Yulianti, N. M. D. R. (2019). Celebrity endorsement, electronic word of mouth and trust brand on buying habits. International Journal of Social Sciences and Humanities, 3(1), 82-90. https://doi.org/10.29332/ijssh.v3n1.261

Semuel, H., \& Wijaya, E. (2010). Corporate social responsibility, purchase intention dan corporate image pada restoran di Surabaya dari perspektif pelanggan. Jurnal Manajemen Pemasaran, 3(1), 35-54.

Tjiptono, F. (2002). Strategi Pemasaran, edisi kedua. Cetakan Keenam. Penerbit. Andy. Yogyakarta.

Rastini, N. M., \& Nurcaya, N. (2019). Customers trust mediation: effect of CSR and service quality towards e-WOM. International Research Journal of Management, IT and Social Sciences, 6(4), 169-173. https://doi.org/10.21744/irjmis.v6n4.670 